\title{
Genetic diversity within and among two-spotted spider mite resistant and susceptible common bean genotypes
}

\author{
Zeinab YOUSEFI ${ }^{1}$, Zahra TAHMASEBI ${ }^{2 *}$, Mohammad Javad Erfani MOGHADAM $^{3}$ and Ali ARMINIAN ${ }^{2}$
}

Received May 08, 2017; accepted November 24, 2017.

Delo je prispelo 08. maja 2017, sprejeto 24. novembra 2017.

\begin{abstract}
Two-spotted spider mite (Tetranychus urticae C. L. Koch, 1836), is one of the most destructive herbivores of common bean. Very little is known about the diversity among resistant sources in this crop. The present study was conducted to characterize 22 resistant and susceptible common bean genotypes by 8 Simple Sequence Repeats (SSRs) and 8 Random Amplified Polymorphic DNA (RAPD) markers. These SSR and RAPD primers produced $100 \%$ and $81.8 \%$ polymorphic bands. Based on RAPD fingerprints and SSR profiles, pairwise genetic similarity ranged from 0.0 to 0.857 and from 0.125 to 1 , respectively. The resistant and susceptible common bean accessions were grouped together in the dendrograms generated from RAPD and SSR clustering analyses. The results indicate that RAPD and SSR analysis could be successfully used for the estimation of genetic diversity among genotypes. SSR markers could group genotypes according to their resistibility and susceptibility to the spotted spider mite but RAPD could not. Therefore, the SSR markers can facilitate the development of resistant common bean cultivars through breeding programs against $T$. urticae.
\end{abstract}

Key words: common bean; two-spotted spider mite; resistibility/susceptibility markers; SSR; RAPD
IZVLEČEK

\section{GENETSKA RAZNOLIKOST NA NAVADNO PRŠICO ODPORNIH IN OBČUTLJIVIH GENOTIPOV NAVADNEGA FIŽOLA}

Navadna pršica (Tetranychus urticae C.L.Koch, 1836) je eden izmed najbolj uničujočih škodljivcev na navadnem fižolu. Zelo malo je znanega o raznolikosti v odpornosti te poljščine na navadno pršico. V raziskavi je bilo ovrednoteno 22 odpornih in občutljivih genotipov navadnega fižola z 8 SSRs markerji (enostavna ponavljajoča zaporedja) in 8 RAPD markerji (naključno pomnožena polimorfna DNK). SSR in RAPD začetni oligonukleotidi so pomnožili $100 \%$ in $81,8 \%$ polimorfnih DNK fragmentov. Na osnovi RAPD vzorcev in SSR profilov, je bila parna genska podobnost med 0,0 do 0,857 in od 0,125 do 1 . Odporne in občutljive akcesije navadnega fižola so se v dendrogramih po klasterski analizi RAPD in SSR združevale skupaj. Rezultati kažejo, da bi bili lahko analizi RAPD in SSR uspešno uporabljeni za določanje genetske raznolikosti med genotipi. SSR markerji bi lahko združevali genotipe glede na njihovo odpornost in občutljivost na navadno pršico, RAPD markerji pa ne. Zaradi vsega naštetega lahko SSR markerji v programih žlatnjenja olajšajo vzgojo na navadno pršico odpornih genotipov navadnega fižola.

Ključne besede: navadni fižol; navadna pršica; odpornost/občutljivost; SSR in RAPD markerji

\section{INTRODUCTION}

Common bean (Phaseolus vulgaris L.) is a widely distributed crop of considerable importance in many countries around the world (Tanyolac, 2013). Genetic diversity information will help breeders in selecting desirable parents in hybrid and new cultivar production and in maintaining population polymorphism. Different types of markers such as morphological markers (Gepts et al., 1986; Singh et al., 1991; Pickersgill et al., 2005; De La Cruz et al., 2005), isozyme markers (Koenig \& Gepts 1989; Santalla et al., 2004; Pickersgill et al.,

1 Graduate M. Sc. Student, Dept. of Agronomy and Plant Breeding, Faculty of Agriculture, Ilam University, Ilam, Iran

2 Assist. Prof., Dept. of Agronomy and Plant Breeding, Faculty of Agriculture, Ilam University, Ilam, Iran. *corresponding author: ztahmasebi@ut.ac.ir

3 Assist. Prof., Dept. of Horticulture, Faculty of Agriculture, Ilam University, Ilam, Iran 
2005), phaseolin types by electrophoretic profiles (Gepts et al., 1986; Pereira \& Souza, 1992; Maciel et al., 1999; Solano, 2005), and molecular markers of Restriction Fragment Length Polymorphism (RFLP) (Pickersgill et al., 2005), Amplified Fragment Length Polymorphism (AFLP) (Maciel et al., 2003), the Random Amplified Polymorphic DNA (RAPD) (Beebe et al., 2000) and Inter Simple Sequence Repeats (ISSR) (De La Cruz et al., 2005) have been used to assess the genetic diversity in common bean. The high density linkage map of common bean was developed using different markers, mainly RAPD (Freyre et al., 1998), SSRs or microsatellite (Yu et al., 2000a; Blair et al., 2003). SSR markers have also been used to evaluate intra-specific diversity within the genus of Phaseolus (Gaitan-Solis et al., 2002) and the fingerprint genetic diversity of common beans (Metais et al., 2002).

Two-spotted spider mite (Tetranychus urticae C. L. Koch, 1836) attacks bean plants in temperate regions and cause great damage to the plant resulting in yield loss (Berlinger, 1986). Plant genetic resistance to the spider mites could be a viable integrated pest management. Phaseolus species possess several natural resistances, that is, constitutive and inducible defence mechanisms against herbivores (Edwards \& Singh, 2006; Ballhorn, 2011).

Quantification of the genetic diversity of common bean genotypes by molecular markers would be of great help to improve the inheritability and durability of herbivore resistance through selection of efficient and diverse combination of parents. Therefore, to increase the introgression of resistance in the common bean genome, molecular markers tightly linked to resistance traits are needed (Bisognin \& Douche, 2002a, 2002b; Pattanayak et al., 2002; Khampila et al., 2008; El_Komy, 2010). There are markers that have been developed for markerassisted selection (MAS) for herbivore resistant genes in common bean (Blair et al., 2010; Blair et al., 2006b).

The main objective of this study was to evaluate the genetic diversity of certain common bean genotypes showing different levels of resistibility and susceptibility to Two-spotted spider mite, using two different PCR-based technologies, SSR and RAPD.

\section{MATERIALS AND METHODS}

\subsection{Plant material}

The plants used in this study were 22 common bean accessions which previously recognized its resistance to Tetranychus urticae C. L. Koch, 1836, (Acari:
Tetranychidae). They were obtained from the Iranian National Common Bean Research Station, Khomein and the Common Bean Gene Bank, Tehran University, Karaj, Iran (Table 1).

Table 1: A list of 22 P. vulgaris accessions used in SSR and RAPD analysis

\begin{tabular}{ccc}
\hline Row & Accession name & Resistance reaction \\
\hline 1 & Daneshkadeh & $\mathrm{MR}$ \\
2 & Black 1115 & $\mathrm{R}$ \\
3 & Jules & $\mathrm{R}$ \\
4 & Marmar & $\mathrm{R}$ \\
5 & Gole & $\mathrm{R}$ \\
6 & KS41128 & $\mathrm{R}$ \\
7 & White 323 & $\mathrm{R}$ \\
8 & Azna & $\mathrm{MR}$ \\
9 & Black 1183 & $\mathrm{R}$ \\
10 & Naz & $\mathrm{R}$ \\
11 & Black 1190 & $\mathrm{R}$ \\
12 & Black 1186 & $\mathrm{R}$ \\
13 & Black 1157 & $\mathrm{R}$ \\
14 & 74-Emerson & $\mathrm{MR}$ \\
15 & Talash & $\mathrm{MR}$ \\
16 & G01437 & $\mathrm{MS}$ \\
17 & D81083 & $\mathrm{MS}$ \\
18 & GOS16 & $\mathrm{MS}$ \\
19 & Sayad & $\mathrm{MS}$ \\
20 & Akhtar & $\mathrm{S}$ \\
21 & G11867 & $\mathrm{S}$ \\
22 & Derakhshan & $\mathrm{S}$ \\
\hline
\end{tabular}

Resistant (R); Moderately Resistant (MR); Moderately Susceptible (MS) and Susceptible (S) 


\subsection{DNA extraction}

For the SSR and RAPD analysis, fresh leaf samples were taken from 10 field grown plants of each accession, bulked and DNA extracted using a modified CTAB method according to Doyle (1987).

\subsection{SSR primers, reactions and agarose gel electrophoresis}

Eight SSR loci (Table 2) obtained from previously reported genomic sequences ( $\mathrm{Yu}$ et al., 2000a; Wang et al., 2012) was used for analysing the entire core collection. PCR reaction volume was $18 \mu$, consisting of $100 \mathrm{ng}$ of DNA, $100 \mathrm{pmol}$ of each primer (forward and reverse), $7 \mu 1$ of CinnaGen PCR master mix, $2 X(0.08$ units $/ \mu \mathrm{l}$ Taq DNA polymerase in reaction buffer, 3 mmol $\mathrm{MgCl}_{2}$, and $1.6 \mathrm{mmol}$ dNTPs). The amplifications were performed with a Thermal Cycler (Applied Bio Rad, Foster City, CA, USA), with an initial $240 \mathrm{sec}$ at $94{ }^{\circ} \mathrm{C}$ that was followed by 10 cycles of: $30 \mathrm{sec}$ at 94 ${ }^{0} \mathrm{C}, 45 \mathrm{sec}$ at annealing temperature $\left(\mathrm{T}_{\mathrm{a}}\right)($ Table 2$)+5^{0} \mathrm{C}$ (as touchdown PCR that enhance the specificity of the initial primer), $120 \mathrm{sec}$ at $72{ }^{\circ} \mathrm{C}$, and then was followed by 25 cycles of: $30 \mathrm{sec}$ at $94{ }^{\circ} \mathrm{C}, 45 \mathrm{sec}$ at $\mathrm{T}_{\mathrm{a}}, 120 \mathrm{sec}$ at $72{ }^{\circ} \mathrm{C}$ and a final extension step at $72{ }^{\circ} \mathrm{C}$ for $420 \mathrm{sec}$. PCR products were separated by electrophoresis in $6 \%$ acrylamide gels, stained with ethidium bromide $(0.8$ $\mathrm{g} / \mathrm{ml}$ ), using $1 \times$ TBE $(89 \mathrm{mmol}$ Tris $/ 1,89 \mathrm{mmol}$ boric acid/l and 2 mmol EDTA/L (pH 8.0) buffer and visualized under ultra-violet light.

Table 2: The list of SSR primers were used for diversity screening

\begin{tabular}{ccc}
\hline GenBank & Primer Sequence (5'-3') & $\begin{array}{c}\text { Annealing } \\
\text { temperature } \\
\left({ }^{0} \mathrm{C}\right)\end{array}$ \\
\hline J04555 & F:GAGGGTGTTTCACTATTGTCACTGC & 49 \\
& R:TTCATGGATGGTGGAGGAACAG & \\
X74919 & F:CCGTTGCCTGTATTTCCCCAT & 47 \\
& R:CGTGTGAAGTCATCTGGAGTGGTC & \\
X80051 & F:AGTTAAATTATACGAGGTTAGCCTAAATC & 48 \\
& R:CATTCCCTTCACACATTCACCG & 49 \\
U77935 & F:CGTTAGATCCCGCCCAATAGT & 49 \\
X79722 & F:CCGTCCAGGAAGAGCGAGC & 47 \\
& R:GCAACCACATTCTTCCCTACGTC & 48 \\
M75856 & F:GAGGGTGTTTCACTATTGTCACTGC & 48 \\
X96999 & R:TGGCACTAAAGCAAAAGAC & 49 \\
JQ739897 & R:CTTATTAAAACGTGAGCATATGTATCATTC & 49 \\
& F:CAGTGGTTATTCTGGGGATT & 48 \\
\hline
\end{tabular}

F: the forward primer sequences; R: the reverse primer sequence

\subsection{RAPD primers, reactions and agarose gel electrophoresis}

Eight RAPD primers (Table 3) were used to assay the genetic diversity of the common bean accessions. The PCR basic reaction was the same as the SSR reaction. The reaction was carried out at $94{ }^{\circ} \mathrm{C}$ for $240 \mathrm{sec}$, then the reaction was cycled 10 times at $93{ }^{\circ} \mathrm{C}$ for $45 \mathrm{sec}, 45$ sec at $\mathrm{T}_{\mathrm{a}}\left(\right.$ Table 3) and extension at $72{ }^{\circ} \mathrm{C}$ for $120 \mathrm{sec}$, and then was followed by 30 cycles of: $45 \mathrm{sec}$ at $93{ }^{\circ} \mathrm{C}$, $60 \mathrm{sec}$ at $\mathrm{T}_{\mathrm{a}}, 120 \mathrm{sec}$ at $72{ }^{\circ} \mathrm{C}$. In addition, a final cycle allowed extension for $420 \mathrm{sec}$ at $72{ }^{\circ} \mathrm{C}$. The amplified products were separated electrophoretically on $1.5 \%$ agarose gels in $1 \times$ TAE buffer, visualized and photographed over a UV transilluminator after staining with ethidium bromide. 
Table 3:. The list of RAPD primers were used for diversity screening

\begin{tabular}{ccc}
\hline Primer name & Primer Sequence $\left(5^{\prime}-3^{\prime}\right)$ & $\begin{array}{c}\text { Annealing } \\
\text { temperature }\left({ }^{\circ} \mathrm{C}\right)\end{array}$ \\
\hline Oligo 12 & CCT GGG TCC A & 38 \\
Oligo 16 & GGG GGC GGG A & 36 \\
Oligo 17 & CCT GGG CCT C & 38 \\
Oligo 32 & GGG GCC TTA A & 37 \\
Oligo 34 & CCG GCC CGA A & 38 \\
Oligo 342 & GAG ATC CCT C & 37 \\
Oligo 345 & GCG TGA CCC G & 36 \\
Oligo 349 & GGA GCC CCC T & 36 \\
\hline
\end{tabular}

\subsection{Scoring and analysis of bands}

Clear and well-marked bands were coded in a binary form by denoting with ' 0 ' and ' 1 ' for absence and presence of bands, respectively, in each genotype. These data were then used as input for further calculations.

The PIC values as described by (Botstein et al., 1980) were used to refer to the relative value of each marker with respect to the amount of polymorphism exhibited. PIC values for each of the primer were estimated using the formula given by $(\mathrm{Nei}, 1973): \mathrm{PIC}=1-\sum(\mathrm{Pij})^{2}$, Where $\mathrm{Pij}$ is the frequency of $\mathrm{j}^{\text {th }}$ allele in $\mathrm{i}^{\text {th }}$ primer and summation extends over ' $n$ ' patterns. PIC is synonymous with the term 'gene diversity' as described by (Weir, 1990). The PIC takes into account not only the number of alleles that are expressed but also the relative frequencies of those alleles (Smith et al., 1997).

To describe genetic relationships among the common bean accessions, RAPD and SSR band data were used to estimate genetic similarity, based on Jaccard similarity coefficients computed using the NTSYSpc 2.02e. Cluster analysis was carried out based on genetic distances using the unweighted pair-group (UPGMA) method in NTSYSpc 2.02e. Dendrograms were created with the TREE program of NTSYSpc 2.02e software (Rohlf, 2000).

\section{RESULTS AND DISCUSSION}

The SSR marker system was used to analyse the genetic diversity of 22 common bean accessions. A total of 18 alleles were detected. The number of alleles per locus ranged from 2-3 bands with an average number of 2.2 alleles per locus that M75856 and J04555 had 3 alleles. These results are in agreement with those of Perseguini (2011) in their study on common bean accessions using SSRs; a mean of 2.8 alleles was reported per SSR. Veloso (2015) obtained an average of 2.5 alleles per locus in a study of genetic divergence of 20 common bean cultivars using 22 polymorphic primers. On the other hand, Blair et al. (2006a) evaluated the genetic divergence of 44 common bean genotypes using 129 microsatellite markers. In that study, an average of 7.8 alleles per locus was observed. Cardoso et al. (2014) obtained an average of 8.29 alleles per locus in a study of genetic divergence of 157 commercial common bean cultivars using 24 polymorphic primers. In this study, an average number of alleles per locus less than the numbers presented by the authors were observed, probably because of the smaller number of genotypes evaluated and the greater kinship among them (Veloso et al., 2015).

It was found that $100 \%$ of the amplification products showed polymorphism, indicating high variation at the DNA level among these accessions. The fragments produced from all the 22 accessions varied in size from 95 to 250 bp (Table 4). 
Genomic SSRs selected on the basis of high polymorphism information content (PIC) successfully helped to discriminate genotypes in the present study. PIC was calculated for all the markers, and was highest for primer J04555 and M75856 which exhibited PIC value of 0.54 and the lowest for the primer X79722 (0.23). The PIC value provides an estimate of the discriminatory power of a locus by taking into account not only the number of alleles expressed, but also the relative frequency of those alleles. Hence, primer J04555 and M75856 were effective and useful markers for determining the genetic differences among the common bean accessions. Wani et al. (2017), in their study on common bean accessions using SSRs, reported that PIC was the highest for primer BMD-6, it exhibited a PIC value of 0.49 and the lowest for the primer BMD2 (0.22). Zargar et al. (2014) showed SSRs a higher PIC value (0.300) compared to RAPDs (0.243). Perseguini et al. (2011) showed PIC from 85 microsatellites used to genotype the 60 carioca common bean accessions ranged from 0.04 to 0.7 . Successful amplifications of expected sizes were obtained.

The data in Table 5 shows the pair-wise similarity matrix based on SSR fingerprints using Jaccard's similarity coefficient. The genetic similarities among the 22 common bean accessions ranged from 0.125 to 1 .

The cluster analysis showed that the 22 accessions were divided into three clusters (Fig. 1). The first cluster included the resistant accessions, Goli, Black-1190, Naz, Black-1186, Black-1183, Black-1157 and Black1115, Jules, Marmar, KS41128, and White-323 and the moderate resistant accessions, Daneshkadeh, Azna and 74-Emerson. The second cluster included Sayad and G01437, D81804 and GOS16 (moderately susceptible) and the T.urticae susceptible accessions, Derakhshan, Akhtar and G11867. The third cluster included only the moderately resistant accession, Talash.

Table 4: The number and size range of bands produced by the SSR and RAPD primers among the 22 common bean accessions

\begin{tabular}{ccccc}
\hline Primer name & $\begin{array}{c}\text { Number of observed } \\
\text { alleles }\end{array}$ & $\begin{array}{c}\text { Fragment length } \\
(\mathrm{bp})\end{array}$ & $\begin{array}{c}\text { Polymorphism } \\
\text { information content } \\
\text { (PIC) }\end{array}$ & Type of marker \\
\hline J04555 & 3 & $125-175$ & 0.54 & SSR \\
X74919(SSR) & 2 & $150-200$ & 0.35 & SSR \\
X80051 & 2 & $200-250$ & 0.40 & SSR \\
U77935 & 2 & $95-100$ & 0.49 & SSR \\
X79722 & 2 & $100-150$ & 0.23 & SSR \\
M75856 & 3 & $140-170$ & 0.54 & SSR \\
X96999 & 2 & $150-200$ & 0.43 & SSR \\
JQ739897 & 2 & $120-150$ & 0.23 & SSR \\
oligo 12 & 1 & 1000 & Monomorphic & RAPD \\
oligo 16 & 1 & 800 & Monomorphic & RAPD \\
oligo 17 & 3 & $1000-1500$ & 0.16 & RAPD \\
oligo 32 & 5 & $200-1500$ & 0.47 & RAPD \\
oligo 34 & 1 & 1200 & Monomorphic & RAPD \\
oligo 342 & 1 & 500 & Monomorphic & RAPD \\
oligo 345 & 4 & $300-1500$ & 0.48 & RAPD \\
oligo 349 & 6 & 0.59 & RAPD
\end{tabular}


Zeinab YOUSEFI et al.

Table 5: Pair-wise genetic similarities based on SSR markers among the common bean genotypes that varied in their resistibility/susceptibility against $T$.urticae

\begin{tabular}{|c|c|c|c|c|c|c|c|c|c|c|c|}
\hline & 1 & 2 & 3 & 4 & 5 & 6 & 7 & 8 & 9 & 10 & 11 \\
\hline 1 & 1 & & & & & & & & & & \\
\hline 2 & 0.5 & 1 & & & & & & & & & \\
\hline 3 & 0.8 & 0.636 & 1 & & & & & & & & \\
\hline 4 & 0.285 & 0.636 & 0.384 & 1 & & & & & & & \\
\hline 5 & 0.285 & 0.636 & 0.384 & 0.636 & 1 & & & & & & \\
\hline 6 & 0.5 & 0.384 & 0.636 & 0.384 & 0.636 & 1 & & & & & \\
\hline 7 & 0.384 & 0.285 & 0.285 & 0.5 & 0.5 & 0.5 & 1 & & & & \\
\hline 8 & 0.5 & 0.384 & 0.384 & 0.384 & 0.636 & 0.636 & 0.8 & 1 & & & \\
\hline 9 & 0.636 & 0.285 & 0.5 & 0.285 & 0.5 & 0.8 & 0.636 & 0.8 & 1 & & \\
\hline 10 & 0.636 & 0.285 & 0.5 & 0.285 & 0.5 & 0.8 & 0.636 & 0.8 & 1 & 1 & \\
\hline 11 & 0.384 & 0.5 & 0.5 & 0.5 & 0.8 & 0.8 & 0.636 & 0.8 & 0.636 & 0.636 & 1 \\
\hline 12 & 0.5 & 0.384 & 0.384 & 0.384 & 0.636 & 0.636 & 0.5 & 0.636 & 0.8 & 0.8 & 0.5 \\
\hline 13 & 0.5 & 0.384 & 0.384 & 0.384 & 0.636 & 0.636 & 0.8 & 1 & 0.8 & 0.8 & 0.8 \\
\hline 14 & 0.636 & 0.285 & 0.5 & 0.285 & 0.5 & 0.8 & 0.636 & 0.8 & 1 & 0.1 & 0.636 \\
\hline 15 & 0.125 & 0.2 & 0.2 & 0.384 & 0.384 & 0.384 & 0.384 & 0.285 & 0.285 & 0.285 & 0.384 \\
\hline 16 & 0.2 & 0.2 & 0.125 & 0.2 & 0.384 & 0.285 & 0.285 & 0.384 & 0.384 & 0.384 & 0.285 \\
\hline 17 & 0.285 & 0.2 & 0.384 & 0.2 & 0.384 & 0.636 & 0.285 & 0.384 & 0.5 & 0.5 & 0.5 \\
\hline 18 & 0.2 & 0.285 & 0.285 & 0.5 & 0.5 & 0.5 & 0.384 & 0.285 & 0.384 & 0.384 & 0.384 \\
\hline 19 & 0.285 & 0.384 & 0.384 & 0.384 & 0.636 & 0.636 & 0.285 & 0.384 & 0.5 & 0.5 & 0.5 \\
\hline 20 & 0.2 & 0.285 & 0.285 & 0.5 & 0.5 & 0.5 & 0.384 & 0.285 & 0.384 & 0.384 & 0.384 \\
\hline 21 & 0.384 & 0.5 & 0.5 & 0.5 & 0.5 & 0.5 & 0.2 & 0.285 & 0.384 & 0.384 & 0.384 \\
\hline 22 & 0.5 & 0.384 & 0.384 & 0.384 & 0.384 & 0.384 & 0.285 & 0.384 & 0.5 & 0.5 & 0.285 \\
\hline \multicolumn{12}{|c|}{ Continued Table 5.} \\
\hline & 12 & 13 & 14 & 15 & 16 & 17 & 18 & 19 & 20 & 21 & 22 \\
\hline 12 & 1 & & & & & & & & & & \\
\hline 13 & 0.636 & 1 & & & & & & & & & \\
\hline 14 & 0.8 & 0.8 & 1 & & & & & & & & \\
\hline 15 & 0.285 & 0.285 & 0.285 & 1 & & & & & & & \\
\hline 16 & 0.5 & 0.384 & 0.384 & 0.384 & 1 & & & & & & \\
\hline 17 & 0.384 & 0.384 & 0.5 & 0.384 & 0.5 & 1 & & & & & \\
\hline 18 & 0.5 & 0.285 & 0.384 & 0.384 & 0.384 & 0.5 & 1 & & & & \\
\hline 19 & 0.636 & 0.384 & 0.5 & 0.285 & 0.5 & 0.636 & 0.5 & 1 & & & \\
\hline 20 & 0.5 & 0.285 & 0.384 & 0.384 & 0.384 & 0.5 & 1 & 0.8 & 1 & & \\
\hline 21 & 0.5 & 0.285 & 0.384 & 0.2 & 0.384 & 0.5 & 0.636 & 0.8 & 0.636 & 1 & \\
\hline 22 & 0.636 & 0.384 & 0.5 & 0.125 & 0.5 & 0.384 & 0.5 & 0.636 & 0.5 & 0.8 & 1 \\
\hline
\end{tabular}




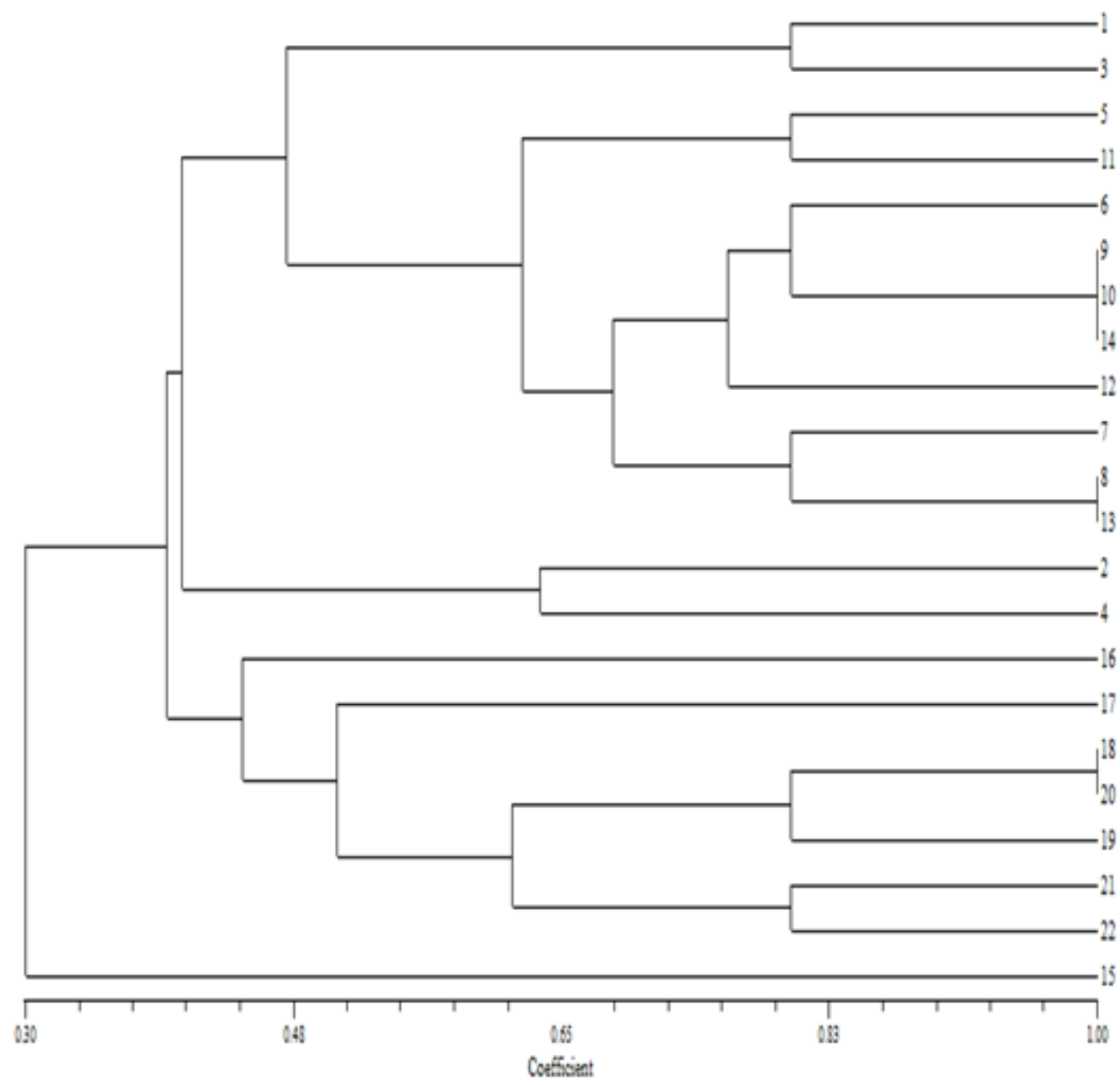

Figure 1: A dendrogram based on SSR markers of the 22 common bean genotypes variations in their resistance to T.urticae

The eight RAPD primers used to fingerprint the 22 common bean accessions generated 22 bands ranging from 100 to $1500 \mathrm{bp}$. Out of these 22 bands, 18 (81.8\%) were polymorphic. The number of alleles per locus ranged from one for oligo 12, oligo 16, oligo 34 and oligo 342 to 6 for oligo 349 with an average number of 2.75 alleles per locus (Table 4). Since four primers out of eight were monomorphic; these primers were excluded from the analysis.

PIC was calculated for all the markers and was the highest for primer oligo349 which exhibited a PIC value of 0.59 and the lowest for the primer oligo 17(0.16). Zargar et al. (2014) observed an average PIC of 0.243 for RAPD in their study on common bean accessions. Bukhari et al. (2015) studied the genetic diversity of common bean, 19 RAPD primers were used and the highest PIC value was recorded as 0.79 with an average PIC value of 0.54 .

Table 6 presents the pairwise genetic similarity estimated among 22 accessions. Pairwise genetic similarity ranged from 0.0 to 0.857 . Based on similarity index, Black-1186 (resistance) and Ks41128 (resistance) and also, G11867 (resistance) and White-323 (susceptible) were the closest ones showing about $90 \%$ similarity. 
Zeinab YOUSEFI et al.

Table 6: Pair-wise genetic similarities based on RAPD markers among the common bean genotypes that varied in their resistibility/susceptibility against T.urticae

\begin{tabular}{|c|c|c|c|c|c|c|c|c|c|c|c|}
\hline & 1 & 2 & 3 & 4 & 5 & 6 & 7 & 8 & 9 & 10 & 11 \\
\hline 1 & 1 & & & & & & & & & & \\
\hline 2 & 0.571 & 1 & & & & & & & & & \\
\hline 3 & 0.727 & 0.6 & 1 & & & & & & & & \\
\hline 4 & 0.416 & 0.272 & 0.636 & 1 & & & & & & & \\
\hline 5 & 0.538 & 0.545 & 0.75 & 0.461 & 1 & & & & & & \\
\hline 6 & 0.545 & 0.272 & 0.636 & 0.6 & 0.461 & 1 & & & & & \\
\hline 7 & 0.222 & 0.33 & 0.2 & 0.0 & 0.181 & 0.11 & 1 & & & & \\
\hline 8 & 0.416 & 0.55 & 0.636 & 0.454 & 0.583 & 0.454 & 0.11 & 1 & & & \\
\hline 9 & 0.333 & 0.3 & 0.416 & 0.5 & 0.5 & 0.363 & 0.0 & 0.363 & 1 & & \\
\hline 10 & 0.461 & 0.33 & 0.538 & 0.636 & 0.4 & 0.5 & 0.0 & 0.5 & 0.545 & 1 & \\
\hline 11 & 0.461 & 0.33 & 0.666 & 0.636 & 0.5 & 0.636 & 0.0 & 0.636 & 0.545 & 0.818 & 1 \\
\hline 12 & 0.454 & 0.3 & 0.545 & 0.66 & 0.384 & 0.5 & 0.0 & 0.363 & 0.75 & 0.7 & 0.7 \\
\hline 13 & 0.416 & 0.4 & 0.5 & 0.454 & 0.461 & 0.33 & 0.0 & 0.454 & 0.66 & 0.636 & 0.636 \\
\hline 14 & 0.333 & 0.181 & 0.416 & 0.363 & 0.285 & 0.363 & 0.0 & 0.363 & 0.4 & 0.7 & 0.7 \\
\hline 15 & 0.4 & 0.1 & 0.363 & 0.444 & 0.231 & 0.44 & 0.0 & 0.181 & 0.5 & 0.5 & 0.5 \\
\hline 16 & 0.3 & 0.428 & 0.4 & 0.5 & 0.25 & 0.33 & 0.0 & 0.333 & 0.375 & 0.4 & 0.4 \\
\hline 17 & 0.222 & 0.333 & 0.2 & 0.25 & 0.181 & 0.25 & 0.0 & 0.25 & 0.285 & 0.2 & 0.2 \\
\hline 18 & 0.2 & 0.285 & 0.181 & 0.375 & 0.166 & 0.22 & 0.0 & 0.222 & 0.25 & 0.3 & 0.181 \\
\hline 19 & 0.5 & 0.333 & 0.6 & 0.75 & 0.416 & 0.55 & 0.0 & 0.4 & 0.625 & 0.6 & 0.6 \\
\hline 20 & 0.3 & 0.428 & 0.4 & 0.5 & 0.363 & 0.33 & 0.0 & 0.33 & 0.571 & 0.4 & 0.4 \\
\hline 21 & 0.307 & 0.272 & 0.384 & 0.6 & 0.461 & 0.33 & 0.0 & 0.33 & 0.66 & 0.5 & 0.384 \\
\hline 22 & 0.333 & 0.3 & 0.416 & 0.5 & 0.5 & 0.363 & 0.0 & 0.4 & 0.75 & 0.416 & 0.416 \\
\hline \multicolumn{12}{|c|}{ Continued Table 6.} \\
\hline & 12 & 13 & 14 & 15 & 16 & 17 & 18 & 19 & 20 & 21 & 22 \\
\hline 12 & 1 & & & & & & & & & & \\
\hline 13 & 0.66 & 1 & & & & & & & & & \\
\hline 14 & 0.55 & 0.5 & 1 & & & & & & & & \\
\hline 15 & 0.714 & 0.444 & 0.5 & 1 & & & & & & & \\
\hline 16 & 0.571 & 0.333 & 0.222 & 0.285 & 1 & & & & & & \\
\hline 17 & 0.285 & 0.25 & 0.0 & 0.166 & 0.5 & 1 & & & & & \\
\hline 18 & 0.25 & 0.222 & 0.0 & 0.142 & 0.4 & 0.666 & 1 & & & & \\
\hline 19 & 0.857 & 0.555 & 0.444 & 0.571 & 0.666 & 0.333 & 0.285 & 1 & & & \\
\hline 20 & 0.571 & 0.4 & 0.222 & 0.285 & 0.6 & 0.5 & 0.4 & 0.666 & 1 & & \\
\hline 21 & 0.5 & 0.454 & 0.25 & 0.3 & 0.333 & 0.25 & 0.375 & 0.555 & 0.5 & 1 & \\
\hline 22 & 0.555 & 0.5 & 0.272 & 0.333 & 0.375 & 0.285 & 0.25 & 0.625 & 0.571 & 0.875 & 1 \\
\hline
\end{tabular}


The cluster analysis showed that the 22 accessions were divided into three clusters (Fig. 2). The first cluster included the moderately resistant accession, Azna and the resistant accessions, jules, Goli, Ks41128, White323 and Black-1115 as well as the moderately susceptible Sayad. The second cluster included G01437 and Sayad (moderately susceptible), and the susceptible accessions, Akhtar and G11867 and the resistant accessions, Black-1183, Black-1186 and Marmarand the moderately resistant accession, Daneshkadeh. The third cluster included the resistant accessions, Naz, Black1190 and Black-1157 and moderately resistant accessions, 14-Emerson and Talash. The fourth cluster included the moderately susceptible accessions, D81804 and Gos16. The fifth cluster included only the susceptible accession, Derakhsan.

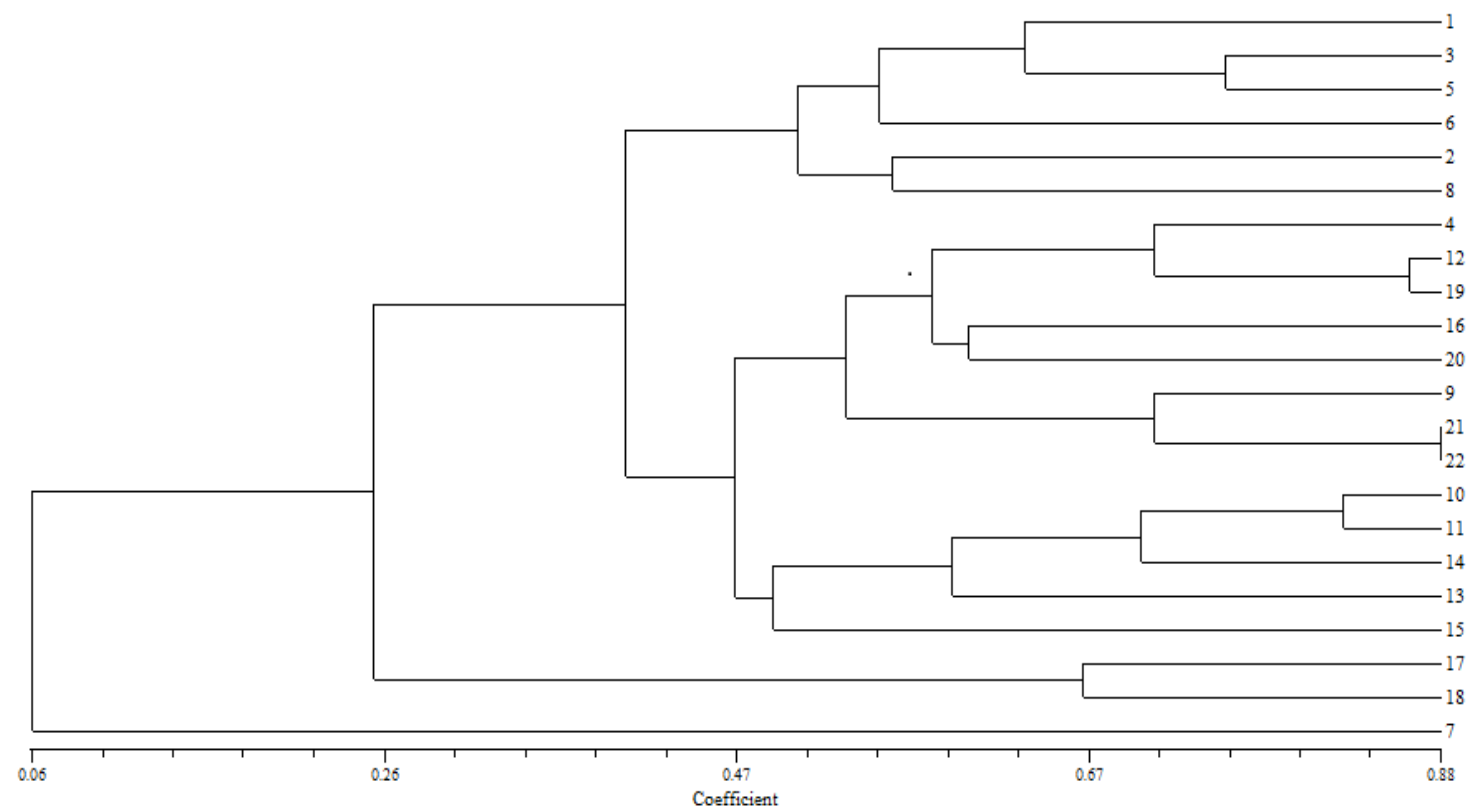

Figure 2: A dendrogram based on RAPD markers of the 22 common bean genotypes variations in their resistance to T.urticae

The results of this study indicate that RAPD and SSR analyses could be successfully used for estimation of genetic diversity among common bean genotypes. SSR markers could group genotypes according to their resistibility/susceptibility to the spotted spider mite but RAPD markers could not. These results are in agreement with those of Tomar et al. (2011) which showed that ISSR and SSR marker systems failed to differentiate the resistant and susceptible soybean cultivars against Rhizoctonia solani J.G. Kühn. Silva et al. (2003) found one RAPD and one SSR marker to be linked in the coupling phase to the angular leaf spot (Phaeoisariopsis griseola (Sacc.) Ferraris) resistant allele but this RAPD marker is not so useful in assisting selection because it is too far from the resistant allele. On the other hand, Wani et al. (2017) showed that primer BMD-6 was observed to be an effective and useful marker to determine the genetic differences among the BCMV (Bean Common Mosaic Virus) resistant common bean accessions. Also, $\mathrm{Yu}$ et al. (2002b) showed the possibility of using RAPD markers to select resistance to common bacterial blight (CCB) and found that one of the RAPD markers was significantly associated with a major quantitative trait locus-conditioning resistance to $\mathrm{CBB}$.

\section{CONCLUSIONS}

In conclusion, this study showed that SSR marker systems have comparable accuracy in grouping genotypes according to their resistibility and susceptibility to the spotted spider mite and can facilitate the development of resistant common bean cultivars through breeding programs against one of the most serious herbivores, two-spotted spider mite. SSRs are characterized by their hyper variability, abundance, reproducibility, Mendelian mode of inheritance and codominant nature (Sicard et al., 2005). The high level of polymorphism of microsatellite markers and their wide cross-species transferability make these new markers 
useful for mapping and molecular characterization of Phaseolus species (Sicard et al., 2005). PIC was the highest for Primer J04555 and M75856; hence, primer J04555 and M75856 were observed to be informative in the present study. Further studies can be carried out to molecularly characterize the SSR unique markers that are associated with T.urticae resistibility/susceptibility described in this study. Since genotypes present in the same clusters have more genetic relationship than the genotypes found in other clusters, this information will help breeders in selecting new cultivar production and in maintaining population polymorphism and developing mapping populations to map the T.urticae resistant gene (s) in common bean genome.

\section{REFERENCES}

Ballhorn, D. J. (2011). Constraints of simultaneous resistance to a fungal pathogen and an insect herbivore in lima bean (Phaseolus lunatus L.). Journal of chemical ecology, 37(2), 141-144. doi:10.1007/s10886-010-9905-0

Beebe, S., Skroch, P. W., Tohme, J., Duque, M. C., Pedraza, F., \& Nienhuis, J. (2000). Structure of genetic diversity among common bean landraces of Middle American origin based on correspondence analysis of RAPD. Crop Science, 40(1), 264-273. doi:10.2135/cropsci2000.401264x

Berlinger, M.J. (1986) Pests. In: J.G. Atherton \& J. Rudich (Eds), The Tomato Crop: A Scientific Basis for Improvement. London: Chapman and Hall. doi:10.1007/978-94-009-3137-4_10

Bisognin, D. A., \& Douches, D. S. (2002a). Early generation selection for potato tuber quality in progenies of late blight resistant parents. Euphytica, 127(1), 1-9. doi:10.1023/A:1019983503697

Bisognin, D. A., \& Douches, D. S. (2002b). Genetic diversity in diploid and tetraploid late blight resistant potato germplasm. HortScience, 37(1), 178-183.

Blair, M. W., Giraldo, M. C., Buendia, H. F., Tovar, E., Duque, M. C., \& Beebe, S. E. (2006a). Microsatellite marker diversity in common bean (Phaseolus vulgaris L.). Theoretical and Applied Genetics, 113(1), 100-109. doi:10.1007/s00122006-0276-4

Blair, M. W., Muñoz, C., Garza, R., \& Cardona, C. (2006b). Molecular mapping of genes for resistance to the bean pod weevil (Apion godmani Wagner) in common bean. Theoretical and applied genetics, 112(5), 913-923. doi:10.1007/s00122-005-0195-9

Blair, M. W., Pedraza, F., Buendia, H. F., Gaitán-Solís, E., Beebe, S. E., Gepts, P., \& Tohme, J. (2003). Development of a genome-wide anchored microsatellite map for common bean (Phaseolus vulgaris L.). Theoretical and Applied Genetics, 107(8), 1362-1374. doi:10.1007/s00122-003-13986
Blair, M. W., Muñoz, C., Buendía, H. F., Flower, J., Bueno, J. M., \& Cardona, C. (2010). Genetic mapping of microsatellite markers around the arcelin bruchid resistance locus in common bean. Theoretical and applied genetics, 121(2), 393-402. doi:10.1007/s00122-010-1318-5

Botstein, D., White, R.L., Skolnick, M.H., \& Davis, R.W. (1980). Construction of a genetic map in man using restriction fragment length polymorphism. American Journal of Human Genetics,3, 314-331.

Bukhari, A., Bhat, M. A., Ahmad, M., \& Saleem, N. (2015). Examination of genetic diversity in common bean (Phaseolus vulgaris L.) using random amplified polymorphic DNA (RAPD) markers. African Journal of Biotechnology, 14(6), 451-458. doi:10.5897/AJB2014.14281

Cardoso, P. C. B., Veiga, M. M., Menezes, I. P. P., Valdisser, P. A. M. R., Borba, T. C., Melo, L. C., ... \& Vianello, R. P. (2013). Molecular characterization of high performance inbred lines of Brazilian common beans. Genetics and molecular research, 12(4), 5467-5484. doi:10.4238/2013.February.6.4

Cardoso, P. C. B., Brondani, C., Menezes, I. P. P., Valdisser, P. A. M. R., Borba, T. C. O., Del Peloso, M. J., \& Vianello, R. P. (2014). Discrimination of common bean cultivars using multiplexed microsatellite markers. Genetics and molecular research, 13(1), 1964-1978. doi:10.4238/2014.March.24.1

De la Cruz, E. P., Gepts, P., GarciaMartin, P. C., \& Villareal, D. Z. (2005). Spatial distribution of genetic diversity in wild populations of Phaseolus vulgaris L. from Guanajuato and Michoacán, México. Genetic Resources and Crop Evolution, 52(5), 589-599. doi:10.1007/s10722-004-6125-x

Doyle, J. J. (1987). A rapid DNA isolation procedure for small quantities of fresh leaf tissue. Phytochem bull, 19, 11-15.

Edwards O and Singh KB (2006). Resistance to insect pests: What do legumes have to offer? Euphytica; 147, 273-285. doi:10.1007/s10681-006-3608-1 
El_Komy, M.H. (2010). Potato resistance and late blight disease. Lap Lambert Academic Publishing.

Gepts, P., \& Bliss, F. A. (1986). Phaseolin variability among wild and cultivated bean germplasm. Journal of Heredity, 76, 447-450. doi:10.1093/oxfordjournals.jhered.a110142

Khampila, J., Lertrat, K., Saksirirat, W., Sanitchon, J., Muangsan, N., \& Theerakulpisut, P. (2008). Identification of RAPD and SCAR markers linked to northern leaf blight resistance in waxy corn (Zea mays var. ceratina). Euphytica, 164(3), 615-625. doi:10.1007/s10681-008-9647-z

Koenig, R., \& Gepts, P. (1989). Segregation and linkage of genes for seed proteins, isozymes, and morphological traits in common bean (Phaseolus vulgaris). Journal of Heredity, 80(6), 455-456. doi:10.1093/oxfordjournals.jhered.a110897

Maciel, F. L., Echeverrigaray, S., Gerald, L. T. S., \& Grazziotin, F. G. (2003). Genetic relationships and diversity among Brazilian cultivars and landraces of common beans (Phaseolus vulgaris L.) revealed by AFLP markers. Genetic Resources and Crop Evolution, 50(8), 887-893. doi:10.1023/A:1025994513043

Maciel, F. L., Gerald, L. T. S., \& Echeverrigaray, S. (1999). Variation in phaseolin and other soluble proteins among cultivars and landraces of common beans of south-Brazil. Journal of Genetics and Breeding, 53, 149-154.

Nei, M. (1973). Analysis of genetic diversity in subdivided population. Proceedings of the National Academy of Sciences of the United States of America, 70, 3321-3323. doi:10.1073/pnas.70.12.3321

Pattanayak, D., Chakrabarti, S.K. \& Naik, P.S. (2002) Genetic diversity of late blight resistant and susceptible Indian potato cultivars revealed by RAPD markers. Euphytica 128(2):183-189. doi:10.1023/A:1020861225738

Perseguini, J. M. K. C., Chioratto, A. F., Zucchi, M. I., Colombo, C. A., Carbonell, S. A. M., Mondego, J. M. C., .. \& Rubiano, L. B. (2011). Genetic diversity in cultivated carioca common beans based on molecular marker analysis. Genetics and molecular biology, 34(1), 88-102. doi:10.1590/S1415-47572011000100017

Pickersgill, B., \& Debouck, D. G. (2005). Domestication patterns in common bean (Phaseolus vulgaris L.) and the origin of the Mesoamerican and Andean cultivated races. Theoretical and Applied Genetics, 110(3), 432-444 doi:10.1007/s00122-004-1842-2
Rohlf, F.J. (2000). NTSYS-pc: numerical taxonomy and multivariate analysis system, version 2.1. New York: Exeter Software.

Santalla, M., Menéndez-Sevillano, M. C., Monteagudo, A. B., \& De Ron, A. M. (2004). Genetic diversity of Argentinean common bean and its evolution during domestication. Euphytica, 135(1), 75-87. doi:10.1023/B:EUPH.0000009543.46471.72

Sicard, D., Nanni, L., Porfiri, O., Bulfon, D., \& Papa, R. (2005). Genetic diversity of Phaseolus vulgaris L. and P. coccineus L. landraces in central Italy. Plant Breeding, 124(5), 464-472. doi:10.1111/j.14390523.2005.01137.x

Silva, G. F. D., Santos, J. B. D., \& Ramalho, M. A. P. (2003). Identification of SSR and RAPD markers linked to a resistance allele for angular leaf spot in the common bean (Phaseolus vulgaris) line ESAL 550. Genetics and Molecular Biology, 26(4), 459463. doi:10.1590/S1415-47572003000400009

Smith, J.S.C., Chin, E.C.L., Shu, H., Smith, O.S., ... \& Wall, S.J. (1997). An evaluation of the utility of SSR loci as molecular markers in maize (Zea mays L.): comparisons with data from RFLPs and pedigree. Theoretical and Applied Genetics, 95,163-173. doi:10.1007/s001220050544

Solano, J. P. L. (2005). Patterns of phaseolins and RAPD analysis in domesticated species of Phaseolus. Revista Fitotecnia Mexicana, 28, 195202.

Tahmasebi, Z., Mohammadi, H., Arimura, G. I., Muroi, A., \& Kant, M. R. (2014). Herbivore-induced indirect defense across bean cultivars is independent of their degree of direct resistance. Experimental and Applied Acarology, 63(2), 217239. doi:10.1007/s10493-014-9770-6

Tahmasebi, Z., Hossein Zadeh, A. H., Bihamta, M.R., Naghavi, M.R., Saboori, A., Dorri, H.R. \& Koshki, M. S. (2011). An investigation on resistance of 19 common bean genotypes to two-spotted spider mite, Tetranychus urticae (Acari: Tetranychidae), in three regions of Iran. Journal of Entomological Society of Iran, 30, 69-78.

Tanyolac, M.B. (2013). SNP (Single Nucleotide Polymorphism) and SSR (Simple Sequences Repeat) Variation in Common Bean. In Plant and Animal Genome XXI Conference. Plant and Animal Genome.

Tomar, J., Saini, N., Goyal, B. S., Tripathi, N., Shrivastava, A. N., Verma, R. K., \& Tiwari, S. (2011). Assessment of genetic diversity among rhizoctonia root rot resistant soybean genotypes. Journal of Food Legumes, 24(4), 267-272. 
Veloso, J. S., Silva, W., Pinheiro, L. R., Dos Santos, J. B., Fonseca Jr, N. S., \& Euzebio, M. P. (2015). Genetic divergence of common bean cultivars. Genetics and molecular research, 14(3), 1128111291. doi:10.4238/2015.September.22.22

Wang, A., Ding, Y., Hu, Z., Lin, C., Wang, S., Wang, B., ... \& Zhou, G. (2012). Isolation and Characterization of 13 New Polymorphic Microsatellite Markers in the Phaseolus vulgaris L. (Common Bean) Genome. International journal of molecular sciences, 13(9), 11188-11193. doi:10.3390/ijms130911188

Wani, A. B., Bhat, M. A., Husaini, A. M., \& Sidiqi, I. (2017). Screening of important bean genotypes/collections for resistance against Common Bean Mosaic Virus using molecular markers. Journal of Pharmacognosy and Phytochemistry, 6(4), 343-347.
Weir, B.S. (1990). Genetic data analysis: Methods for discrete population genetic data (Sinauer Associates, Inc, Sunderland, MA.

Yu, K., Park, S. J., \& Poysa, V. (2000a). Marker-assisted selection of common beans for resistance to common bacterial blight: efficacy and economics. Plant breeding, 119(5), 411-415. doi:10.1046/j.1439-0523.2000.00514.x

Yu, K., Park, S. J., Poysa, V., \& Gepts, P. (2000b). Integration of simple sequence repeat (SSR) markers into a molecular linkage map of common bean (Phaseolus vulgaris L.). Journal of Heredity, 91(6), 429-434. doi:10.1093/jhered/91.6.429

Zargar, S. M., Farhat, S., Mahajan, R., Bhakhri, A., \& Sharma, A. (2016). Unraveling the efficiency of RAPD and SSR markers in diversity analysis and population structure estimation in common bean. Saudi journal of biological sciences, 23(1), 139149. doi:10.1016/j.sjbs.2014.11.011 